\title{
NOMINALIZING -ING AS A CASE OF AFFIX BORROWING: AN FDG ACCOUNT*
}

\author{
Daniel García Velasco \\ Universidad de Oviedo
}

\begin{abstract}
In this paper, I explore a particular type of borrowing into the Spanish language, the use of the English suffix -ing with Spanish bases, and provide an account of both its emergence in the language and its use in peninsular Spanish which is compatible with the general architecture of Functional Discourse Grammar and the theory of verbal interaction in which the grammar component is integrated. First, I introduce some relevant notions of contact-induced language change, lexical and affix borrowing and their motivating factors. Next, I describe the widespread use of -ing Anglicisms in the Spanish language with special attention to hybrid forms containing Spanish bases. I address the question whether the use of English -ing suffix with Spanish bases qualifies as a case of direct or indirect affix borrowing and I conclude that the process shows signs of both at the same time. In the second part of the paper, I integrate my findings in the theory of Functional Discourse Grammar. I argue that the Contextual Component is crucial both in accounting for the motivation of this borrowing and the derivational use of the suffix, which is introduced directly from the context and feeds the Morphosyntactic encoder.
\end{abstract}

KeYwords: -ing Anglicism, affix borrowing, language contact, Functional Discourse Grammar.

\section{EL SUFIJO NOMINALIZADOR -ING COMO UN CASO DE PRÉSTAMO: UNA PROPUESTA DE ANÁLISIS EN FDG}

\section{RESUMEN}

En este artículo se analiza un caso particular de préstamo lingüístico: el uso del sufijo inglés -ing con bases nativas y se da cuenta de su aparición y uso en el español peninsular de forma que resulta compatible con la arquitectura general de la Gramática Discursivo Funcional. En primer lugar, se introducen nociones relevantes del cambio lingüístico motivado por el contacto entre lenguas. A continuación, se describe el uso de anglicismos con el sufijo -ing en el español con especial referencia a formas híbridas que contienen bases nativas. Se trata la cuestión de si este fenómeno ilustra un caso de préstamo directo o indirecto y se concluye que muestra signos de ambos. En la segunda parte del artículo se integran estas observaciones en el marco de la Gramática Discursivo Funcional. Se argumenta que el Componente Contextual resulta crucial tanto para dar cuenta de la motivación del préstamo como del uso derivativo del sufijo, que es inicialmente introducido desde el contexto al codificador morfosintáctico.

Palabras Clave: Anglicismos en -ing, préstamo de afijos, contacto entre lenguas, Gramática Discursivo Funcional.

DOI: https://doi.org/10.25145/j.recaesin.2020.80.07

Revista Canaria de Estudios Ingleses, 80; April 2020, pp. 123-143; ISSN: e-2530-8335 


\section{INTRODUCTION: LANGUAGE CONTACT AND ANGLICISMS IN SPANISH}

Intensive language contact typically takes place in bilingual or multilingual communities, in which speakers are confronted with different languages and linguistic settings on a regular basis. Studies on language contact pay special attention to the sociolinguistic and structural factors that motivate processes of language change. One of the most obvious processes of contact-induced language change is 'borrowing', which is defined by Matras (146) as "a kind of import of a structure or form from one language system into another". Matras (149) also claims that the most widely cited motivating factors for borrowing are "gaps in the structural inventory of the recipient language, and the prestige enjoyed by the donor language." Obvious examples of gaps include lexical items that name cultural activities, institutions and technologies available in the community of the donor language, but not in that of the recipient language, whereas the 'prestige' factor suggests that "speakers imitate elements of the speech of a socially more powerful, dominant community in order to gain approval and social status." (150).

Spanish-speaking and English-speaking communities are in close contact in the United States. According to the Hispanic Map of the United States 2018 issued by the Cervantes Institute, there are 41 million Spanish speakers in the US, according to the latest available data, whereas English is now the sole language of 237 million people. In this situation, speakers are likely to alternate the use of elements from both languages in the same linguistic expression, a process known as code-switching, which necessarily involves bilingual speakers. In monolingual communities, however, it is not two linguistic codes that alternate, but elements of one language are merely borrowed into another.

As noted by Gómez Rendón (13), however, it is not necessary for two linguistic communities to occupy the same geographical space for borrowing to take place. He cites the obvious case of English, which is nowadays massively disseminated through the media, which results in speakers of other languages incorporating English elements in their languages. In Spanish, this is particularly evident in the widespread use of Anglicisms in fields like sport, technology or fashion, whose introduction is probably motivated by the main two factors cited above: the social prestige that the English language enjoys as a language of popular culture, science and technology, and its related use as a global lingua franca, and the technical and cultural innovations which are imported from English speaking communities.

* Thanks are due to Frank Seifart for valuable comments on a previous version of this article and to Taresa Fernández Lorences, Kees Hengeveld and Hella Olbertz for collecting examples of -ing Anglicisms for me. 
In this article I am particularly interested in a subset of Anglicisms in peninsular Spanish, those ending in the derivational noun-forming suffix -ing ${ }^{1}$. The reason why I believe these borrowings are of particular interest is first, because they seem to form a class of their own in the lexicon, and secondly, because their existence seems to underlie the spread of suffix -ing to native bases, a process which will take centre stage in this contribution.

As a first approximation, -ing borrowings may be classified into four main categories (see Mott and Balteiro 160):

1. True borrowings: The English term is adopted with no changes in meaning and / or spelling: casting, jogging.

2. Adaptations: The English term is adopted, but its meaning or function changes slightly: parking, catering.

3. Pseudo-anglicisms: These are forms which sound English, but do not really exist in the English language: footing.

4. Hybrid formations: These are forms which make use of English suffix -ing, but on Spanish bases: puenting, balconing.

The four categories illustrate a cline of integration in the lexicon of the Spanish language. Items in group one are less integrated in that the English item keeps both its original form and meaning; speakers intend to reproduce the English pronunciation of the term and thus implicitly acknowledge their foreign status. The items in the second group are also English items, but their forms or meanings have been slightly adapted. In Spanish, the English present participle 'parking' refers to what the British would call a 'car park' and Americans a 'parking lot'. 'Catering' would be rendered in English as a 'catering company'. It is for this reason that Mott (191) considers Spanish 'catering' a pseudo-Anglicism obtained through a process of truncation. It is interesting to observe that Spanish seems to borrow -ing forms for nominal use and not for adjectival use (see footnote 1), which may motivate this truncation process.

Items in group three are considered pseudo-anglicisms because they sound like English words to Spanish ears, but do not exist in the English language. The prototypical case is that of 'footing', which, according to Mott has in fact been taken from French. In any event, this is probably the less productive group of all. Items in group four illustrate the complete integration of the affix in the grammatical inventory of the language and its use with native bases. Thus, the form 'puenting' is obtained from the combination of the Spanish for 'bridge' (puente) plus English -ing suffix and refers to the activity of 'bungee jumping'; 'balconing' (from Sp. balcón) refers to the act of jumping into a swimming pool from a balcony, an activity usually performed by young British holiday-makers in Spanish resorts, frequently leading

${ }^{1}$ Obviously, -ing is also an inflectional affix in English forming present participles, which can in turn function as nominal premodifiers (e.g. the barking dog). -ing forms which are borrowed into Spanish do not show this adjectival function. 
to fatal accidents. The final stage in this process of integration is the orthographic adaptation of the terms (removal of final ' $\mathrm{g}$ ' as the velar nasal $/ \mathrm{y} /$ is not a distinctive phoneme in Spanish), which obscures both its English origin and its morphological structure. A quick search on the online version of Diccionario de la Real Academia de la Lengua $(\mathrm{DRAE})^{2}$ for words ending in the sequence 'in' gave the following Anglicisms adapted to Spanish orthographic and phonological conventions:

$$
\text { esmoquin (smokingjacket), filin (feeling), mitin (meeting), trávelin (travelling) }
$$

Note that this situation is common in lexical borrowing. As Matras (146) observes:

Bilingual speakers may well be aware of the origin of a word or morpheme in a particular 'donor' language, but this awareness may be blurred over time, especially if active bilingualism declines, or when use of the item spreads to monolingual sectors of the speech community. Not only is there no intention to return the 'borrowed' item to its rightful 'owner', but for most speakers its original 'ownership' may not always be traceable.

Items in group four are particularly interesting for a number of reasons. The attachment of the noun forming suffix -ing illustrates a case of 'affix borrowing'. Although this phenomenon is well-attested in many languages, scholars agree that the borrowing of bound morphemes is a much more restricted process, for there must exist structural compatibility among the two languages. Thus, in the different borrowing hierarchies and constraints proposed in the literature (see Matras 153165 for discussion), it is agreed that bound morphemes are less likely to be borrowed than full content lexical items or free morphemes.

In spite of this, the examples of words in the fourth group seem to be on the increase in peninsular Spanish, a fact which is probably motivated by the speakers' desire to play with language and sound innovative and fashionable. Indeed, this use of the -ing suffix with Spanish bases is particularly noticeable in the field of advertising, where I have attested most of the following nonce formations: ${ }^{3}$

\section{a. cinking (cinco 'five')}

A pun. The word refers to a five-year warranty provided by Hyundai cars. At the same time, it sounds similar to English 'thinking'.

${ }^{2}$ https://dle.rae.es/. But note that 'esmoquin' is originally a truncated participle (Mott) and filin is defined as "Estilo musical romántico surgido en la década de 1940" (Romantic musical style which emerged in the forties). This contrasts with the much more spread use of 'feeling' in Spanish in expressions such as 'tener feeling'.

3 The definitions and explanations given are mine and have been constructed on the basis of the information available in the context of use. 
b. Aurging (Aurgi, a car repair company)

The intended reading probably tries to emphasise the (presumably) good service of the company.

\section{c. sonrising (sonrisa 'smile' $(\mathrm{N})$ )}

To enjoy something. This has been taken from an advertising campaign by a travel agency, which also included forms like 'crucering' and 'vacacioning'.

\section{d. sofing (sofá 'sofa')}

Probably to rest and do nothing. Advertising campaign by Conforama, a furniture store.

e. disfruting (disfrutar 'enjoy')

A brand name for a financial services company.

f. edredoning (edredón, 'duvet')

To hide underneath a duvet to have sex avoiding being recorded by cameras (coined in the TV show Big Brother).

g. duerming (from an irregular form of the verb dormir 'sleep')

A brand name for a hotel chain.

h. viding (vida 'life')

A brand name for a house selling company.

i. vueling (vuelo 'flight')

A brand name for a Spanish airline company.

Mott (185) also discusses the case of 'metring' (riding on the back of underground trains) and adds forms such as 'bicing' (a brand name for a bike rental shop) and 'sanfermining' (to enjoy the San Fermín festivity).

As is common with many neologisms, these forms typically arise within a restricted group of speakers and, to the extent they successfully spread to the entire linguistic community, become conventional units of the language. Thus, in their initial stages of use, they would need a great deal of contextual information to be properly decoded. Morphologically, the process seems to be very flexible. Although noun forming -ing attaches to verbs only in English, it combines with different word classes in the Spanish language: nouns (sonrisa, sofá), numerals (cinco), proper nouns (Aurgi) or verbs (disfrutar, dormir). Thus, these items denote an action typically or contextually associated with the referent of the item they attach to (e.g. 'sofing' denotes the action typically associated with a sofa, i.e. lying or resting). The Spanish language lacks a morphological process of word-class conversion or zero-derivation, which, in languages like English, allows lexemes to be used in different functions. -ing derivation thus serves to create action nominals from different parts of speech adding a significant degree of flexibility to the language. Indeed, the Spanish language has 
a number of suffixes to derive process nominals, but they all operate on verbs and leave many lexical gaps. Note that forms such as sonrisa are resultative nominals themselves, but crucially, the derived -ing form 'sonrising' denotes a non-resultative or process nominal, thus increasing the expressive potential of the language. There is no process nominal which can be obtained from the verb sonreir through the application of conventional derivational suffixes. Romero Lesmes additionally notes that it is very frequent for -ing forms to be inserted in the productive 'hacer +nominal' construction, in which the semantic load is carried by the noun that combines with the light verb hacer. This construction thus emphasises the nonresultative contribution of the -ing nominal.

In the following section, I will explore the main properties of morphological borrowing through language contact with particular reference to the -ing suffix in combination with Spanish bases.

\section{DIRECT AND INDIRECT AFFIX BORROWING}

Affix borrowing is a well-attested process in the literature on language contact. As noted by Matras, there is a crucial difference between the borrowing of lexemes containing morphemes of the donor language and the productive use of those morphemes in the recipient language. It is only in the latter case that an affix can be said to have been borrowed (Matras 209-210):

In defining morphological borrowing, we must distinguish the mere acceptance of morphology along with borrowed lexical items, from the diffusion of morphology beyond the borrowed lexicon itself; and further, between 'backwards diffusion', that is, replication of borrowed morphs in connection with pre-existing, inherited lexicon, and 'forward diffusion', that is, the productive use of borrowed morphs with newly acquired vocabulary. (...) At the very least, backwards diffusion is a pre-requisite for recognising a 'morphological' loan, as opposed to a mere portion of a lexical loan.

In other words, affix borrowing is defined after the productive use of the borrowed affix with native stems and not merely by the borrowing of items containing a foreign suffix.

As mentioned earlier, affix borrowing is not the most frequent type of borrowing, but it is nevertheless well-attested. The linguist Frank Seifart ("Afbo") has created an online survey of borrowed affixes in the languages of the world. His database "comprises descriptions of 101 cases of affix borrowing, i.e. cases where one language borrowed at least one affix from another language, involving a total of 657 borrowed affixes".

Seifart ("Direct") deals with the question of how affixes are borrowed into languages. He notes (see also Winford and Matras) that the traditional view on affix borrowing is that foreign affixes are incorporated into recipient languages indirectly. First, a number of loanwords containing the affix are borrowed into the recipient language, which allows speakers (probably much later, he argues) to start using the 
affix with vernacular bases. Seifart (Direct 512), however, proposes an alternative scenario, in which affixes are directly borrowed from a donor language:

Under direct borrowing, an affix is recognized by speakers of the recipient language in their knowledge of the donor language and used on native stems as soon as it is borrowed, with no intermediate phase of occurring only in complex loanwords. The fundamental difference between these two scenarios for how an affix is borrowed is thus from where speakers take the affix prior to using it on native stems: from complex loanwords in the recipient language (indirect borrowing), or from their knowledge of the donor language (direct borrowing).

A necessary condition for direct affix borrowing is therefore good knowledge of the donor language itself and of the properties of the affix in that language, so that speakers need not rely on the previous borrowing of complex items containing the suffix.

The use of suffix -ing with Spanish bases, therefore, poses an interesting theoretical question, namely, whether the suffix is directly borrowed from English or indirectly through its identification in the set of -ing Anglicisms which are employed in Spanish. In order to answer this question, it is necessary to see in more detail the properties of each borrowing type in relation to the presence of -ing forms in Spanish.

\subsection{INDIRECT BORROWING}

Winford (387) notes that a good number of derivational affixes have entered the English language indirectly:

Lexical borrowing from French also had some influence on English morphology, particularly on derivational processes. It introduced several derivational affixes such as the prefixes in dis-connect, de-flee, en-rich, em-bolden, etc. Similarly, items like cert-ify, charit-able, declar-acioun, statu-ette, etc., yielded various suffixes, some of which became relatively productive as early as the Middle English period itself. For instance, the adjective-forming suffix -able, was soon employed with native stems to yield words like spekable, knowable, etc. (...).

According to Seifart (Direct 514), the following three criteria must be met for indirect affix borrowing to take place:

Criterion 1. There is a set of complex loanwords containing a borrowed affix which have a common, recognizable meaning component, for example, a set of words that contain the same affix and that all denote properties or possibilities, such as profitable, honorable, deceivable, and so forth.

Criterion 2. There is a set of pairs of loanwords, one with and one without the affix, with constant, recognizable changes in meaning, for example, pairs of simplex loanwords and complex loanwords, where the complex loanwords denote 
the property or possibility of what the simplex loanwords express, for example, profit-profitable, honor-honorable, deceive-deceivable, and so forth.

Criterion 3. Within pairs of complex loanwords and corresponding simplex loanwords, complex loanwords have a lower token frequency than the corresponding simplex loanwords; for example, profitable is less frequent than profit.

The first criterion seems to be the most important one of the three for two reasons: first, indirect affix borrowing is impossible in the absence of complex loanwords containing the affix, and secondly, because the higher the number of loanwords introduced in a given language, the more likely indirect affix borrowing may be. The online version of DRAE lists the following 20 -ing Anglicisms in Spanish, which could therefore be considered cases of well-established lexemes in the language: ${ }^{4}$

\begin{tabular}{cc|}
\hline \multicolumn{2}{c|}{ TABLE 1: -ing ANGLICISMS IN DRAE } \\
\hline antidumping & living \\
\hline camping & marketing \\
\hline casting & overbooking \\
\hline catering & parking \\
\hline dumping & puenting \\
\hline footing & rafting \\
\hline holding & ranking \\
\hline jogging & sparring \\
\hline leasing & standing \\
\hline lifting & windsurfing \\
\hline
\end{tabular}

However, the number of -ing Anglicisms in use in everyday language is likely to be much bigger. In order to get a more realistic idea of the impact of -ing forms in actual speech I have examined the Corpus del Español del Siglo XXI de la Real Academia de la Lengua (CORPES). ${ }^{5}$ It contains 237.678 documents which amount to 225 million words. In order to avoid an intractable number of hits I limited my search to non-fictional Internet-based texts in Peninsular Spanish. The search gave 1938 -ing ending forms, but this set includes many items of no relevance for the present study: e.g. proper names such as King, Smashing Pumpkins, Wyoming, Chinese words such as Xiaoping or English words which populate Spanish texts in song titles, names of web pages, etc. and which do not count as -ing borrowings proper. After careful depuration, I obtained the forms listed in (3). It should be noted that these

\footnotetext{
${ }^{4}$ Note that this list includes the false Anglicism 'footing' and the hybrid formation 'puenting'.

https://www.rae.es/recursos/banco-de-datos/corpes-xxi.
} 
items are given in a Spanish context with no explanation of their meaning, which indicates that they are expected to be familiar to the intended addressees:

Trekking, happening, brainstorming, coaching, training, piercing, merchandising, zapping, doping, consulting, rebranding, mobbing, networking, hosting, snorkelling, kayaking, shopping, peeling, packaging.

Similarly, different studies on Anglicisms in Spanish provide additional forms collected by their authors. Romero Lesmes gives the forms chatting, leasing, mailing, outsourcing, or petting. In the field of medicine, Navarro cites the following: banding, binding, blotting, clamping, clapping, dumping, flapping tremor, imprinting, kindling, lifting, mapping, monitoring, piercing, priming, screening, splicing, stretching and training. In fashion Balteiro provides the following Anglicisms: body painting, bowling, branding, casting, cool hunting, fitting, flushing, grooming, jeggings, knitting, legging(s), lifting, lipofilling, making of, packaging, piercing(s), rebranding, running, shooting, shopping, skin needling, sparkling, styling, tailoring and volumizing.

Consequently, I think we can safely conclude that there is a good number of -ing Anglicisms in use in everyday language, which would allow speakers to recognize the existence of a consistent nominal class and, through analogical reasoning, extend the use of the affix to native bases. However, Matras (211) notes that this criterion is not decisive:

Although it is a pre-requisite and a trigger for morphological borrowing, lexical borrowing on its own does not seem to constitute a very powerful motivation to replicate derivational procedures. Considering the amount of Romance vocabulary in English and the transparency of the derivational morphology that is contained in it, the diffusion of productive Romance derivational morphology into inherited (Germanic) lexemes in English must be described as rather modest.

In other words, the existence of loanwords with the relevant affix is a necessary condition, but it is not enough to justify its indirect borrowing.

Seifart's second criterion for indirect affix borrowing, however, should not be interpreted as a necessary condition as the previous one. It may be possible to identify an affix on the basis of complex loanwords only, but the presence of the corresponding forms without the affix "makes an affix even more salient, however, as these pairs allow speakers to directly experience the segmentability and the meaning contribution of the affix" (Direct 514). As for the present study, the corresponding forms without suffix -ing are not used in the Spanish language on a regular basis (market, jog, park, etc.), so this factor does not seem to facilitate indirect borrowing. However, as this is not a necessary condition, it might be the case that speakers could identify the affix even in the absence of simple forms just on the basis of the set of -ing Anglicisms in the language.

In order to check whether that is the case, I conducted a small survey with fourteen students of English at an absolute beginner's level. The survey, which is provided in the appendix, contains three -ing Anglicisms of the DRAE list (marketing, parking, overbooking), the hybrid form 'puenting', and a number of distractors, which 
included an Anglicism ending in the sequence -ing (ring) and the forms pudin and mitin, adapted to Spanish orthographic norms. Informants were asked to identify morphemes (or word parts, as I put it to avoid technicalities), as in the example provided. Although it was applied to a limited number of speakers, the survey showed some interesting results. For the four relevant words, the number of speakers that could identify the presence of the -ing suffix is given in table 2 :

\begin{tabular}{ccc}
\hline \multicolumn{3}{c}{ TABLE 2: SURVEY RESUlTS } \\
\hline Anglicism & Correct Answers & Percentage \\
\hline Marketing & 4 & 28.5 \\
\hline Puenting & 5 & 35 \\
\hline Parking & 5 & 35 \\
\hline Overbooking & 2 & 14 \\
\hline
\end{tabular}

In the best of cases, only five out of the fourteen speakers interviewed could identify the morpheme, a rather low $35 \%$. It is interesting to observe that a significant number of speakers provided the wrong morpheme segmentation, reanalysing the suffix as part of the syllable initiated by the preceding consonant, e.g par-king, marketing, and even puen-ting. This is thus a clear indication that they do not perceive the existence of the English affix in its original form, although it might also be claimed that they do perceive the existence of a meaningful morpheme in those words.

Finally, Seifart's third criterion builds on previous studies on morphological processing that show how complex words which have a low token frequency relative to their bases (Hay) facilitate analysability, as this increases a rule-driven processing rather than a direct retrieval of the lexeme from the mental lexicon. In that case, the affix is more visible and this helps its dissemination to native bases. However, given that the stems of the -ing Anglicisms are not generally used in the Spanish language, -ing Anglicisms are necessarily more frequent than their bases for Spanish speakers, which means that this third criterion is not met.

On the basis of these observations, it seems to me that the evidence for indirect affix borrowing for the English affix -ing in Spanish is rather limited. In fact, it is only the first criterion of the three which is fully compatible with an indirect borrowing scenario, and although it is a necessary criterion in the process, it is not decisive, as has been argued. Hence, it seems adequate to explore whether the direct borrowing approach better explains the process.

\subsection{Direct borrowing}

According to Seifart (Direct 515), for direct borrowing to take place it is necessary that speakers possess relevant knowledge of the donor language "since in the absence of such knowledge, the only way to get an affix is from complex loanwords". Following Winford, Seifart notes that affix borrowing "typically occurs in bilingual 
speech communities where the donor language becomes increasingly dominant for recipient language speakers". He notes, however, that it is not necessary for speakers of the recipient language to have full command of the donor language as they

may also create hybrid formations while speaking -or code-switching to- the donor language if they had already acquired the donor-language affix, but not yet relevant donor-language stems. The crucial step for direct affix borrowing to occur is that these recipient-language speakers then use these affixes in recipientlanguage morphosyntactic frames also, creating further hybrid formations. (...) recipient-language speakers furthermore need to be influential among the recipient language community, so that the spread of the hybrid formations throughout that community is enabled.

In other words, the ideal situation for direct borrowing to take place is intensive contact between the two languages and good knowledge of both donor and recipient language by those speakers who use foreign affixes with recipient language stems. Obviously, this is not the case here as the use of the -ing suffix in peninsular Spanish is not the result of extensive contact between two linguistic communities in a situation of bilingualism.

However, there is one additional relevant factor, as Seifart (Direct 515) notes that recipient language speakers need to be "influential among the recipient language community, so that the spread of the hybrid formations through that community is enabled". Indeed, the role of socio-cultural factors in language contact processes has been repeatedly stressed by different scholars. Gómez Rendón (15) observes the different roles played by the speech community and speakers as agents of contactinduced language change. In his work, he emphasizes the active role of speakers as instigators of changes in linguistic communitarian practices. He argues:

One condition for the spreading of individual changes in verbal behaviour is the innovative role of the individual speaker in the speech community as determined by his/her political and economic position but also by his/her linguistic proficiency in higher and lower varieties in diglossic situations.

It is interesting to observe that many of the -ing hybrid formations are created in the field of advertising, as already indicated, a discipline which, by its very nature intends to be influential and is assumed to determine the trends or products which are fashionable and (arguably) necessary in contemporary society. It is therefore reasonable to claim that publicists are influential individuals in society and their use of the language is deemed appropriate by other members of the linguistic community. At the same time, it is also to be expected that, as qualified professionals, they should show an operative command of the English language at least at an intermediate level, enough to guarantee knowledge of English suffix -ing and its several uses. Similar reasons are provided by Balterio in her study of -ing forms in the field of fashion, and Mott (193), who argues that "there can be no justification for many of the ing forms that are used in Spanish other than the desire to impress and make other people believe that the speaker is up to date in linguistic usage". This is obvious in 
cases such as 'viding' or 'duerming', which contribute little meaning and certainly do not fill a lexical gap in the Spanish language.

A cursory look at the situation of English as a second language in Spain may be illustrative. Eurostat, the statistical office of the European Union, offers relevant data on the situation of foreign language learning in European countries. Particularly relevant for present purposes are the pages on 'Self-reported language skills' (languages $>$ self-reported language skills). Table 3 gives relevant data on the command of the best known foreign language in Spain by groups of professionals in 2016. It is compared in the table with mean data from the 28 EU countries. Note that, although the exact best-known language in Spain is not indicated, it can be no other than English, as it is the most spoken second language both in the European Union and Spain: ${ }^{6}$

\begin{tabular}{lcccccc}
\hline \multicolumn{5}{c}{ TABLE 3: SELF-REPORTED LANGUAGE SKILLS BY GROUPS } \\
OF PROFESSIONALS (EUROSTAT)
\end{tabular}

The table shows that there is a significant difference in proficiency between qualified professionals and those having elementary occupations. 68.3 per cent of the latter and 67.8 per cent of skilled manual workers admit having basic knowledge of English, which contrasts with only 27.7 of qualified professionals, who declare good and proficient command of English (44.5 and 27.5 respectively). Under the assumption that these professionals exert social influence, the prestige factor which both Matras and Seifart consider relevant in borrowing seems to be at stake, especially in a field as prominent for the creation of social tendency as advertising. Note that good command of the second language is a prestige factor in itself as

${ }^{6}$ The table (Pupils by education level and modern foreign language studied - absolute numbers and $\%$ of pupils by language studied), also by Eurostat, indicates that $99.7 \%$ of Spanish students in secondary education (general) take English as their first second language. The levels of English are defined as follows: Basic: "I can understand and use the most common everyday expressions. I use the language in relation to familiar things and situations"; Good: "I can understand the essential of clear language and produce simple text. I can describe experiences and events and communicate fairly fluently"; Proficient: "I can understand a wide range of demanding texts and use the language flexibly. I master the language almost completely". 
"[m]onolingual speakers often learn non-native lexicon by imitating bilinguals for reasons of linguistic fashion” (Gómez Rendón 49).

It seems to me then that the existence of a set of established Anglicisms in the Spanish language together with the prestige and influence of those speakers who first coin and use -ing forms with Spanish bases is a clear explanatory factor of the way this suffix is being used nowadays and its spread in the language. What we seem to have, then, is a combination of two factors, one typical of indirect affix borrowing and another one of direct affix borrowing as an explanation for the use of the -ing suffix with Spanish stems. This is nicely in line with the conclusion defended by Seifart (Direct 528-29) himself, who claims that it is often a combination of both processes which accounts for affix borrowings between languages:

Even if indirect borrowing is likely to have been the primary process, direct borrowing may also contribute to affix identification as long as there is relevant knowledge of the donor language by speakers of the recipient language at the time of the spread of the affix to native stems. It may even be argued that such knowledge would necessarily be used for the creation of hybrid formations (...) The approach taken here is thus to assume that affix borrowing usually involves both direct and indirect processes, and to assess the relative contribution of each of these processes.

There are thus two main factors which together contribute to the use of -ing with Spanish stems: (i) the existence of a relevant number of complex loanwords containing the suffix and (ii) the fact that its application to native bases occurs in influential activities such as advertising by equally influential speakers with good knowledge of the donor language. Consequently, it can be claimed that both aspects of indirect and direct borrowing contribute to the use and spread of the affix in the Spanish language.

Finally, it should be noted that there is a tendency for the affix to become phonologically integrated in a complete syllable and to become orthographically obscured along the instructions provided by the Real Academia de la Lengua Española. As mentioned earlier, Winford (387) claims that "relatively few of the many French affixes that had been imported became productive, and the vast majority of French loans underwent adaptation to English morphological processes".

There is reason to believe that this might also be the fate of -ing suffix in the Spanish language. The forms in example (1) provide a good test bed to check whether language users prefer the original English spelling or rather follow the Hispanicized version. The CORPES corpus gives us just 92 instances of the form 'meeting', but 1259 instances of the orthographically adapted mitin (4). In the case of 'feeling' vs. filin, the former wins 255 to 40, as shown in (5), but esmoquin wins out too by the figures given in (6):

(4) a. meeting 92

b. mitin: 1259

(5) a. feeling: 255

b. filin: 40 
If this tendency continues, it might well be that the -ing suffix is not borrowed after all, as it will become obscured and unrecognizable for most speakers within an ordinary syllable. In spite of this, the current state of the process shows an interesting case of language borrowing and poses a challenge for any grammatical theory interested in the dynamics of language use and language change. In the following section I will thus evaluate how Functional Discourse Grammar takes up that challenge.

\section{FDG AND CONTACT-INDUCED LANGUAGE CHANGE}

Functional Discourse Grammar (FDG), as presented in Hengeveld and Mackenzie ("Functional") and Keizer ("Functional English"), is a functionaltypological theory of language structure which intends to meet a number of standards of adequacy for grammars. These include those proposed by Dik for Functional Grammar (psychological adequacy, typological adequacy and pragmatic adequacy) and others which have also been proposed by different scholars since then: acquisitional adequacy (Boland) and diachronic adequacy (Bakker, 1; Butler and Gonzálvez-García, 137; see Hengeveld and Pérez Quintero, 104 for the relation among standards and Butler for a careful reappraisal of standards of adequacy).

In spite of this alleged interest in showing the compatibility of the theory with diachronic studies, FDG has paid little attention to language change, and to the extent it has, it has mostly been with reference to grammaticalization processes (Hengeveld "Hierarchical") and the lexical / grammatical dichotomy (Keizer "LexicalGrammatical” and Pérez Quintero "Grammaticalization"). Thus, Hengeveld shows how the model can make adequate predictions as to which grammaticalization paths are possible in languages on the basis of the layered structure of the different levels of representation which the theory proposes. To my knowledge, however, nothing has been said in FDG about contact-induced language change. Works like Bakker ("Language change"), Bakker and Hekking ("Functional") and Gómez Rendón ("Typological") stand in the FG tradition, and therefore do not make use of the FDG technical apparatus, although their functional orientation makes them obviously relevant for FDG. It is therefore appropriate to evaluate the extent to which current FDG is compatible with the factors behind contact-induced borrowing and whether the general architecture of the model also finds confirmation in language change motivated by language contact.

It should be noted at the outset that grammaticalization is essentially a language internal process in which a fully lexical element gradually becomes a grammatical unit, with concomitant loss of semantic and lexical properties. Obviously, the motivation of grammaticalization processes is to be found in the dynamics of language use, but the analyses proposed to deal with this phenomenon in its different manifestations have been constructed on the basis of language 


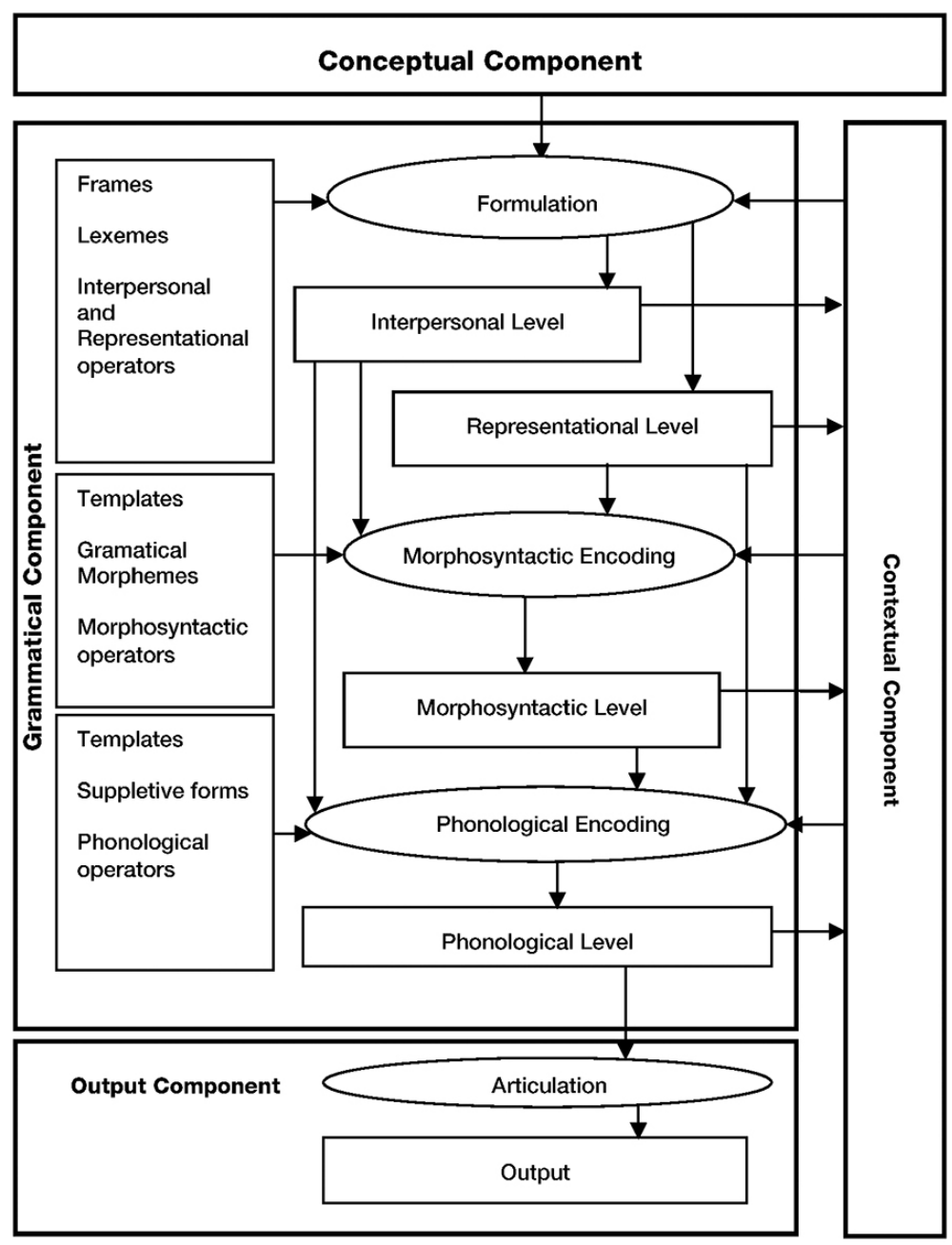

Figure 1. General layout of FDG (Hengeveld and Mackenzie 13).

internal principles. Contact-induced language change, however, is motivated by both linguistic and extralinguistic factors, and as argued in this paper for the case of -ing borrowing into peninsular Spanish, social aspects such as good knowledge of English as a second language and the social prestige and status of those speakers who creatively make use of this suffix with native stems, are undoubtedly behind the spread and use of this form.

One relevant property of FDG is that the grammar component is integrated in a wider theory of verbal interaction which includes a number of additional components. The full architecture of FDG is given in figure 1. 
I will not provide a detailed explanation of the FDG architecture here. For current purposes, it will suffice to highlight that the grammar component is surrounded by three additional components (the Conceptual, the Contextual and the Output Components) which are necessary to provide a complete account of human verbal behaviour. In particular, the Contextual component contains the "immediate information received from the Grammatical Component concerning a particular utterance which is relevant to the form that subsequent utterances may take" and "long-term information about the ongoing interaction that is relevant to the distinctions that are required in the language being used, and which influence formulation and encoding in that language" (Functional 9-10). This is indicated in figure 1 with relevant arrows from context to morphosyntactic encoding and from the Morphosyntactic Level to context.

An obvious example of the relation between context and grammar involves the encoding of active entities (e.g. a highly active referent will most likely be encoded pronominally rather than by means of a full noun phrase). This process is obviously dependent upon a previous utterance as represented in the Morphosyntactic Level (e.g. a full noun phrase), which makes the referent active in current discourse and will call for a pronominal encoding in subsequent utterances.

As for the long-term information which is included in the Contextual Component, FDG makes it clear that it does not intend to provide a complete account of all the general information which can potentially have an influence on linguistic choices (to the extent that task is possible at all), but only those contextual distinctions that have a systematic effect on grammar. While this may be a sensible strategy in the synchronic description of languages, processes of language change are necessarily gradual and produce fluctuations in the use of language by different and sometimes by even the same speaker. An account of language change, then, probably calls for a less strict view of the relation between grammar and context than FDG allows (see Butler "Reappraisal" and Connolly "Contextual" for similar positions on different grounds).

What about the social factors that play a role in contact-induced language change? The motivating factor of 'prestige', which I have argued to be relevant in the spread and use of the -ing suffix with Spanish stems, is not a property with systematic effects on the choice of that affix, given the obvious fact that speakers under similar socio-linguistic influence may decide not to use -ing Anglicisms at all. Butler (35) discusses the possibility of adding 'sociocultural adequacy' to the set of quality standards for functional grammars and concludes that the standard position in FDG is reluctant to include in the Contextual component sociolinguistic factors that lead to probabilistic choices. He claims that Hengeveld and Mackenzie ("Grammar") indeed note the relevance of those factors in linguistic behaviour but they believe they probably lie at the interface between the theory of verbal interaction and speakers' cognitive-inferential abilities. There is no doubt, however, that if FDG intends to be compatible with processes of language change, it becomes necessary to explore the nature of that interface relation.

Assuming then that the Contextual Component can provide linguistically relevant information (even if that leads to probabilistic choices only), including 
knowledge of a second language and of social practices and relations, competent speakers may extract linguistic information from their knowledge of English as a second language, and be also affected by the social prestige of highly valued speakers as a motivating factor in linguistic usage. Note that this situation is fully compatible with the existence of a number of -ing Anglicisms in the lexeme inventory of these speakers, another motivating factor for the use of this suffix with native bases.

Finally, for those speakers who, through recurrent usage, may have incorporated the -ing suffix as part of the stock of derivational suffixes in Spanish, the morpheme should be simply included in the set of morphemes feeding the morphosyntactic encoder.

Let us now see one detailed example of the process. As mentioned earlier, the form 'puenting' is a well-established case of a hybrid formation in Spanish. One possible analysis would assume that the form is ready-made in the lexicon, which is undoubtedly the case of those speakers who can naturally use the item in spite of having little or no knowledge of English at all, and cannot therefore recognize the existence of complex structure in that form. For those speakers who can recognize the compositional structure of the item and make use of the -ing suffix as a derivational noun-forming affix in Spanish, two analyses seem possible: either the suffix is part of the inventory of morphemes of the language, a possibility which seems reasonable for those Spanish speakers who actively create -ing forms (e.g. publicists), or the suffix is taken from the Contextual Component directly and feeds the Morphosyntactic encoder in the generation of a particular utterance. Both processes seem to be compatible with a direct borrowing scenario, but only the first with an indirect one.

In both cases, however, the construction of the form 'puenting' would involve retrieving a relevant frame from the lexicon and its combination with the nominal lexeme puente. Given that the form puenting denotes an action, the noun is inserted in an eventive frame as in (7):

$$
\left(e_{i}:\left(f_{i}: \text { puente }\left(f_{i}\right)\left(e_{i}\right)\right)\right.
$$

At the Morphosyntactic Level the form is inserted in a Nominal word frame, which triggers the addition of the -ing suffix:

$$
\left(\mathrm{Nw}_{\mathrm{i}}:\left[\left(\mathrm{Ns}_{\mathrm{j}} \text { : puente }\left(\mathrm{Ns}_{\mathrm{j}}\right)\right)\left(\mathrm{Naff}_{\mathrm{i}}: \operatorname{ing}\left(\mathrm{Naff}_{\mathrm{i}}\right)\right)\right]\left(\mathrm{Nw}_{\mathrm{i}}\right)\right)
$$

The suffix -ing would then be formally triggered by the insertion of an eventdenoting form in an unexpected frame, the lack of a productive affix in the language to derive process nominals from event-denoting units, and the extra linguistic factors of social prestige and trendiness associated with the English language nowadays. Note that Spanish also has the form puentear, which is also obtained from the noun puente, but has different meaning (to bypass someone / to fail to notice somebody's opinion or higher position), which would result from the insertion of the same representational unit (7) in a morphosyntactic verbal frame (for the treatment of derivational morphology in FDG see García Velasco and Keizer and the papers in Guerrero Medina and Portero Muñoz). 


\section{CONCLUSIONS}

In this paper, I have explored the compatibility of FDG with contact-induced language change as exemplified by the case of -ing borrowings into peninsular Spanish with particular attention to the combination of this suffix with native stems. I have argued that the process shows signs of both direct and indirect affix borrowing (Direct) and that it is motivated by the existence of an established set of -ing Anglicisms in the language and the social prestige and good command of English as a second language by qualified professionals. The examination of this process clearly shows that sociolinguistic features are relevant factors in contact-induced language change. Therefore, linguistic theories which aim at being compatible with what is known about language change and evolution should allow external social factors to potentially have an impact on the linguistic system in their general architecture.

In the second part of this article, I have shown how my findings can be incorporated into FDG. On the one hand, an FDG-based linguistic analysis of the process seems to provide an adequate account of the use of -ing with native bases. Moreover, the theory allows the description of the different scenarios of the use of this suffix by Spanish speakers: (i) as a conventional suffix in the stock of morphemes feeding the Morphosyntactic Level, or (ii) as a unit taken from the Contextual Component on every occasion of use. This second possibility, however, although fully compatible with FDG's general architecture, proves the relevance of extra-grammatical sociolinguistic factors as motivating forces of language change, and probably entails a more flexible approach to the relation between context and grammar than FDG has been willing to allow so far.

Reviews sent to author: 28 January 2020

Revised paper accepted for publication: 8 February 2020 


\section{WORKS CITED}

Bakker, Dik. "Language Change: Some Implications for the Theory of Functional Grammar". Working Papers in Functional Grammar 66 (1998).

Bakker, Dik \& Ewald Hekring. “A Functional Approach to Linguistic Change Through Language Contact: The Case of Spanish and Otomí”. Working Papers in Functional Grammar 71 (1999).

Balteiro, Isabel. “The Influence of English on Spanish Fashion Terminology: ing forms”. ESP Today 2 (2014): 156-173.

Boland, Anerieke. Aspect, Tense and Modality: Theory, Typology and Acquisition. Utrech: LOT. 2006.

Butler, Christopher S. "A Reappraisal of the Functional Enterprise with Particular Reference to Functional Discourse Grammar. Revista Canaria de Estudios Ingleses 67 (2013): 13-42.

Butler, Christopher S. \& Francisco Gonzálvez-García. Exploring Functional-Cognitive Space. Amsterdam: John Benjamins, 2014.

Connolly, John H. "The Contextual Component Within a Dynamic Implementation of the FDG Model: Structure and Interaction”. Pragmatics 24 (2014): 229-248.

Dik, Simon C. The Theory of Functional Grammar. Part 1: The Structure of The Clause. 2nd revised edition, ed. by Kees Hengeveld. Berlin: Mouton de Gruyter, 1997.

Eurostat (2016). “Self-Reported Language Skills” (27 October 2019). Web < https:/lec.europa.eu/ eurostat/web/education-and-training/data/database>.

García Velasco, Daniel \& Evelien Keizer. "Derivational Morphology in Functional Discourse Grammar". Theory and Practice in Functional-Cognitive Space Ed. María de los Ángeles Gómez González, Francisco José Ruiz de Mendoza Ibáñez \& Francisco GonzálvezGarcía. Amsterdam \& Philadelphia: John Benjamins, 2014. 151-175.

Guerrero Medina, Pilar \& Portero Muñoz, Carmen. "Derivational Morphology in Functional Discourse Grammar.” Special issue of Word Structure 11.1 (2018).

Gómez Rendón, Jorge. Typological Constraints on Language Contact: Aremindian Languages in Contact with Spanish. II vols. Utrech: LOT, 2008.

Hay, Jennifer. “Lexical Frequency in Morphology: Is Everything Relative?” Linguistics 39.6 (2001): 1041-1070.

Hengeveld, Kees. "A Hierarchical Approach to Grammaticalization”. The Grammaticalization of Tense, Aspect, Modality and Evidentiality: A Functional Perspective. Ed. Kees Hengeveld, Heiko Narrog \& Hella Olbertz. Berlin: Mouton de Gruyter, 2017. 13-38

Hengeveld, Kees, \& María Jesús Pérez Quintero. “Descriptive Adequacy in Functional Grammar”. Revista Canaria de Estudios Ingleses 42 (2001): 103-117.

Hengeveld, Kees, \& J. Lachlan Mackenzie. Functional Discourse Grammar. Oxford: Oxford UP, 2008.

Hengeveld, Kees, \& J. Lachlan Mackenzie. "Grammar and Context in Functional Discourse Grammar”. Pragmatics 24 (2014): 203-227.

Keizer, Evelien. “The Lexical-Grammatical Dichotomy in Functional Discourse Grammar.” Alfa: Revista de Lingüistica 51.2 (2007): 35-56.

Keizer, Evelien. A Functional Discourse Grammar of English. Oxford: Oxford UP, 2015.

Matras, Yaron. Language Contact. Cambridge: Cambridge UP, 2009. 
Мотт, Brian. "The Rise of the English -ing Form in Modern Spanish: A Source of Pseudo-Anglicisms." Pseudo-English. Studies on False Anglicisms in Europe. Ed. Cristiano Furiassi \& Henrik Gotтlieb. Berlin: Mouton de Gruyter, 2015. 175-196.

Navarro, Fernando A. "La anglización del español: mucho más allá de bypass, piercing, test, airbag, container y spa." Traducción: contacto y contagio. Actas del III Congreso Internacional "El español, lengua de traducción”, Puebla (México) del 12 al 14 de julio del 2006. Ed. Luis GonzÁlez \& Pollux HernúńEz. Bruselas: Esletra, 2008. 213-232.

Pérez Quintero, María Jesús. "Grammaticalization vs. Lexicalization: The Functional Discourse Grammar View.” Revista Canaria de Estudios Ingleses 67 (2013): 97-121.

Romero Lesmes, María Dolores. "Las construcciones con el verbo hacer y un anglicismo nominal en -ing". CHIMERA. Romance Corpora and Linguistic Studies 2 (2015): 35-48.

Seifart, Frank. AfBo: A World-Wide Survey of Affix Borrowing. Leipzig: Max Planck Institute for Evolutionary Anthropology, 2013 (27 October 2019). Web http://afbo.info/.

SEIfART, Frank. "Direct and Indirect Affix Borrowing”. Language 91 (2015): 511-532.

Winford, Don. “Contact-Induced Change: Classification and Processes”. Diachronica 22 (205): 373-427. 


\section{APPENDIX}

ENCUESTA SOBRE MORFOLOGÍA DEL ESPAÑOL

Si su lengua materna no es el español, indique cuál:

Instrucciones: en español, una palabra como "extraterreste» se compone de dos partes: «extra»y «terreste», que en conjunto contribuyen a crear su significado «fuera de la tierra». En otros casos, también podemos distinguir dos partes, aunque una de ellas aporte significado en menor medida, como, por ejemplo, "casas», que se compone de "casa» y la «s», que solo indica la noción de plural.

Las siguientes palabras se utilizan habitualmente en el español y todas aparecen recogidas en el Diccionario de la Real Academia de la Lengua. Diga si contienen una, dos o tres partes e indique cuáles, como en el ejemplo que se ofrece:

\begin{tabular}{|c|c|c|c|c|}
\hline Palabra & 1 PARTE & 2 PARTES & 3 PARTES & Partes \\
\hline Extraterrestre & & $\mathrm{X}$ & & Extra-terrestre \\
\hline \multicolumn{5}{|l|}{ Submarino } \\
\hline \multicolumn{5}{|l|}{ Flor } \\
\hline \multicolumn{5}{|l|}{ Marketing } \\
\hline \multicolumn{5}{|l|}{ Apendicitis } \\
\hline \multicolumn{5}{|l|}{ Puenting } \\
\hline \multicolumn{5}{|l|}{ Mitin } \\
\hline \multicolumn{5}{|l|}{ Psicología } \\
\hline \multicolumn{5}{|l|}{ Pudin } \\
\hline \multicolumn{5}{|l|}{ Popurri } \\
\hline \multicolumn{5}{|l|}{ Parking } \\
\hline \multicolumn{5}{|l|}{ Prever } \\
\hline \multicolumn{5}{|l|}{ Overbooking } \\
\hline \multicolumn{5}{|l|}{ Charlatán } \\
\hline Ring & & & & \\
\hline
\end{tabular}


